\title{
Sea Ice Monitoring in the European Arctic Seas Using a Multi-Sensor Approach
}

\author{
Stein Sandven \\ Nansen Environmental and Remote Sensing Center, Bergen, Norway
}

\begin{abstract}
Advances in satellite remote sensing of sea ice and icebergs in Arctic regions are described in case studies showing the benefits of using multi-sensor observations. It is demonstrated how Synthetic Aperture Radar (SAR) used in combination with optical images can improve discrimination of open water, nilas, young ice and three gradations of deformed first-year ice. The classification method is based on multi-sensor data fusion and neural network, where in situ observations were used for training of the algorithm. Synergetic use of scatterometer and passive microwave (PMW) data is well-established to estimate large scale ice motion, but in straits and marginal seas more detailed ice drift data are needed. In the Fram Strait SAR images from ENVISAT have been used to estimate ice drift and ice area flux since early 2004. It is demonstrated that SAR wideswath images can provide more accurate and higher-resolution ice drift vectors compared to scatterometer and PMW data. Methods for retrieval of thickness for thin ice are available using thermal infrared, passive microwave and SAR data, but these methods are research-oriented and not used in regular monitoring. Laser and radar altimeter measurements from satellites have shown promising capability to observe sea ice freeboard and thickness for ice thicker than about one meter. Such data used in combination with ice drift and ice types will provide new estimates of ice volume variability and fluxes. SAR and optical data have also been used to observe icebergs in the Barents Sea. The two data types are complementary and can improve iceberg detection if they are used in combination.
\end{abstract}

\section{Introduction}

The most mature satellite method for sea ice observation is large-scale ice concentration and ice extent measurements by passive microwave (PMW) radiometer data. A number of retrieval algorithms have been developed and intercompared over the last three decades (e.g. Andersen et al. 2006) 
It is generally agreed that the accuracy in ice concentration and extent estimates from PMW data is in $5-10 \%$ except for the melt season. Time series of ice extent and area from these data show that the total ice area in the Arctic has been reduced by $3-4 \%$ per decade since 1978 , while the multi-year ice area has been reduced by $7 \%$ per decade in the same period (Johannessen et al. 1999, 2004).

Observation of sea ice has improved significantly by use of satellite Synthetic Aperture Radar (SAR) images, providing detailed information on ice types, ice motion, ice edge, leads, polynyas, ridges, fast-ice boundaries, freezing and melting. In the last decade extensive SAR data sets have been used for ice monitoring in many ice-covered areas (e.g. Kwok and Cunningham 2002; Johannessen et al. 2007) An overview of remote sensing data used for observation of sea ice variables is given in Table 1.

Table 1. Sea ice variables and remote sensing sensors.

\begin{tabular}{|c|c|c|}
\hline Ice variable & Remote sensing data & Products \\
\hline $\begin{array}{l}\text { Area, extent and } \\
\text { concentration }\end{array}$ & $\begin{array}{l}\text { PMW data } \\
\text { Scatterometer data } \\
\text { optical/IR data }\end{array}$ & $\begin{array}{l}\text { Global maps are available daily from } \\
\text { SSMI, AMSR-E, and scatterometer } \\
\text { data. Regional ice charts using SAR, } \\
\text { optical and IR data }\end{array}$ \\
\hline Ice thickness & $\begin{array}{l}\text { Radar altimeter/Laser } \\
\text { altimeter, IR, SAR }\end{array}$ & $\begin{array}{l}\text { Large-scale maps are provided by ERS } \\
\text { and IceSat data. Improved products } \\
\text { from CRYOSAT after } 2009 \text {. Thin ice } \\
\text { retrieval from IR and SAR data }\end{array}$ \\
\hline Ice drift & $\begin{array}{l}\text { PMW data } \\
\text { Scatterometer data } \\
\text { SAR wideswath and } \\
\text { Global Mode data }\end{array}$ & $\begin{array}{l}\text { Large-scale ice drift products are from } \\
\text { scatterometer and PMW data for the } \\
\text { non-melt season. SAR-based ice drift } \\
\text { is available for selected regions. }\end{array}$ \\
\hline $\begin{array}{l}\text { Ice-snow albedo } \\
\text { and surface temp }\end{array}$ & Optical/IR images & $\begin{array}{l}\text { Research activity, pathfinder data sets } \\
\text { are produced }\end{array}$ \\
\hline $\begin{array}{l}\text { Ice type classifi- } \\
\text { cation }\end{array}$ & $\begin{array}{l}\text { Scatterometer, SAR } \\
\text { and PMW }\end{array}$ & $\begin{array}{l}\text { Multi-year and first-year products are } \\
\text { available, young and first-year ice can } \\
\text { be retrieved from SAR }\end{array}$ \\
\hline Ice roughness & Radar and laser & Ice roughness maps are shown using \\
\hline & Altimeter, SAR & $\begin{array}{l}\text { Icesat data. SAR can provide data on } \\
\text { deformation }\end{array}$ \\
\hline $\begin{array}{l}\text { Icebergs in the } \\
\text { Arctic }\end{array}$ & $\begin{array}{l}\text { High resolution optical } \\
\text { and SAR images }\end{array}$ & $\begin{array}{l}\text { Maps are produced as part of sea ice } \\
\text { services. Detailed mapping with high- } \\
\text { resolution images is a research activity }\end{array}$ \\
\hline
\end{tabular}

This chapter presents four examples of improved retrieval of sea parameters using the multi-sensor approach: ice classification, ice drift and flux retrieval, ice thickness and iceberg detection. 


\section{Ice classification by synergy of SAR and optical data}

A number of ice classification methods using SAR and other satellite data have been developed in the last two decades, but robust classification methods have not yet been developed and few algorithms are used in operational monitoring systems (e.g. Tsatsoulis and Kwok 1998; Onstott and Shuchman 2004; Johannessen et al. 2007) In practical ice analysis of SAR images, human interpretation is mostly used for classification of ice types and ice processes. Recent results on SAR ice analysis and classification have been published by e.g. Bogdanov et al. (2007).

It is demonstrated here that combining two types of SAR images with optical images can improve the classification of five-six ice types (i.e. open water, grease ice, nilas, young ice, undeformed and deformed firstyear ice) The example shown in Figure 1 is from a typical winter situation in the Kara Sea, where the ice cover consists of various levels of new, young and first-year ice. The images obtained over the same area on the same day are ERS-2 SAR, RADARSAT ScanSAR, and a Meteor 3/5 optical image. The pixels in the RADARSAT image were normalized in range to be comparable to the ERS pixels, compensating for the difference incidence angle of the two SAR images. The study was done during a field experiment with the nuclear icebreaker Sovetsky Soyuz, collecting in situ observations of ice types in the study area (Bogdanov et al. 2005).

The ice in the study area consisted mostly of medium and thick firstyear ice, and coastal polynyas with thin ice (Figure 1) New and young ice has low radiance in visual imagery, which increases as the ice becomes thicker. The dark signature of the SAR images in region A corresponds to grease ice and nilas in a refreezing polynya. The dark area in the lower right corner of the optical image is also a polynya consisting of grey or grey-white ice with thickness of 10-20 cm. The bright signature in the SAR images in region B corresponds to greyish signature in the optical image, indicating that this is young ice with thickness up to $30 \mathrm{~cm}$. The ice floes in area $\mathrm{C}$ are undeformed first-year ice with low backscatter in the SAR images and high reflectance in the optical image due to the snow cover on top of the ice. Area D has mainly first-year ice of medium deformation, mixed with some young ice with brighter SAR signature than the first-year ice. Area E contains highly deformed first-year ice with higher backscatter than medium deformed first-year ice. The optical image cannot distinguish between different levels of deformation since the signal depends mainly on the albedo of the snow cover.

The classification method used in this example is based on a multisensor data fusion algorithm described by Bogdanov et al. (2005) where a number of pre-defined ice classes with training data sets for each of the 
classes were used as input to the algorithm. The six sea ice classes were: smooth, medium deformed and deformed first-year ice, young ice, nilas, and open water. The results from classification of the two SAR images are shown in Figure 2a while the results from the classification with the optical image included are shown in Figure 2b.

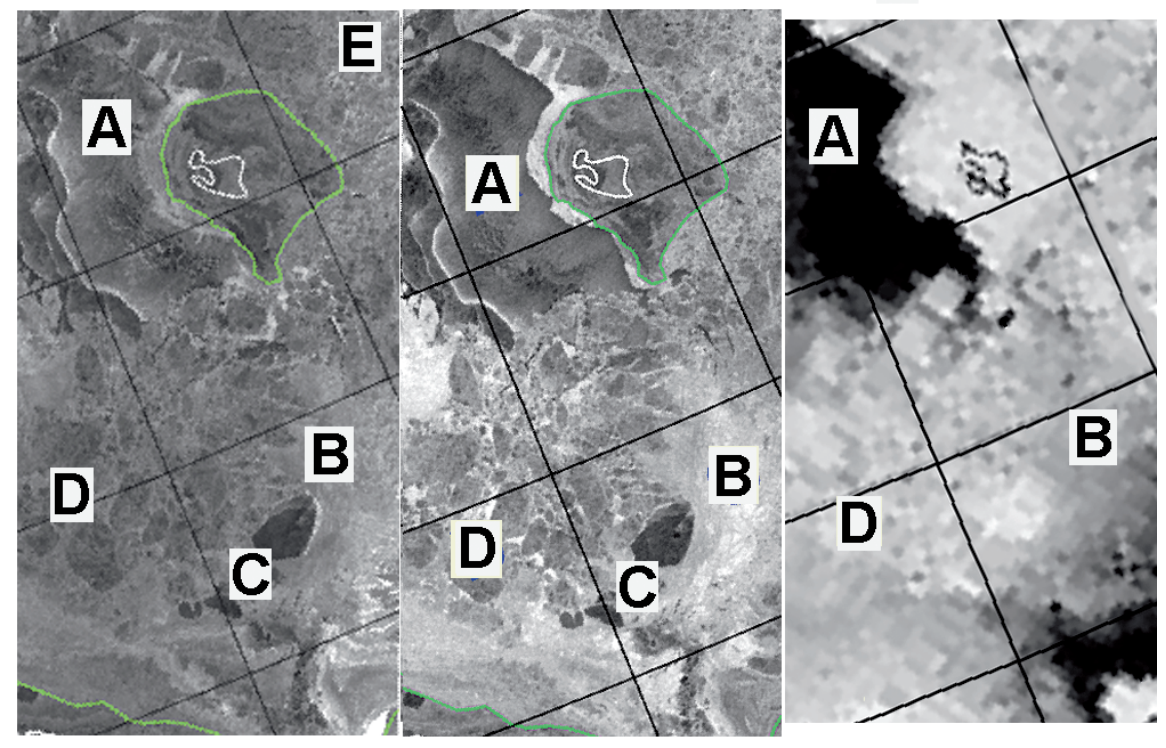

Fig. 1. Sea ice area in the Kara Sea mapped by three types of satellite data on 30 April 1998. Left: ERS-2 SAR; middle: RADARSAT ScanSAR Wide; and right: optical image from Meteor 3/5. The coastline surrounding the island in the upper part of the image and the fast-ice border in the lower part of the image are superimposed on the SAR images. The main ice types in the images are A: nilas, B: young ice, C: first-year level ice, D: first-year medium deformed ice, and E: firstyear very deformed ice.

The young ice and first-year ice classes are quite similar in the tworesults, whereas the main improvement is found for the nilas where inclusion of the optical image makes a significant impact. The large nilas in the upper left region (area A in Figure 1) and the smaller nilas in the lower right corner are more correctly classified. The open water class is not found within the study region. To quantify the classification results, a number of test data sets were selected for each of the six classes. The percentage correct classification increased from $75 \%$ to $85 \%$ by including the optical image. The possibility to improve ice classification further is possible by including infrared radiometer data providing temperature measurements and SAR data with multipolarization and other frequencies. 

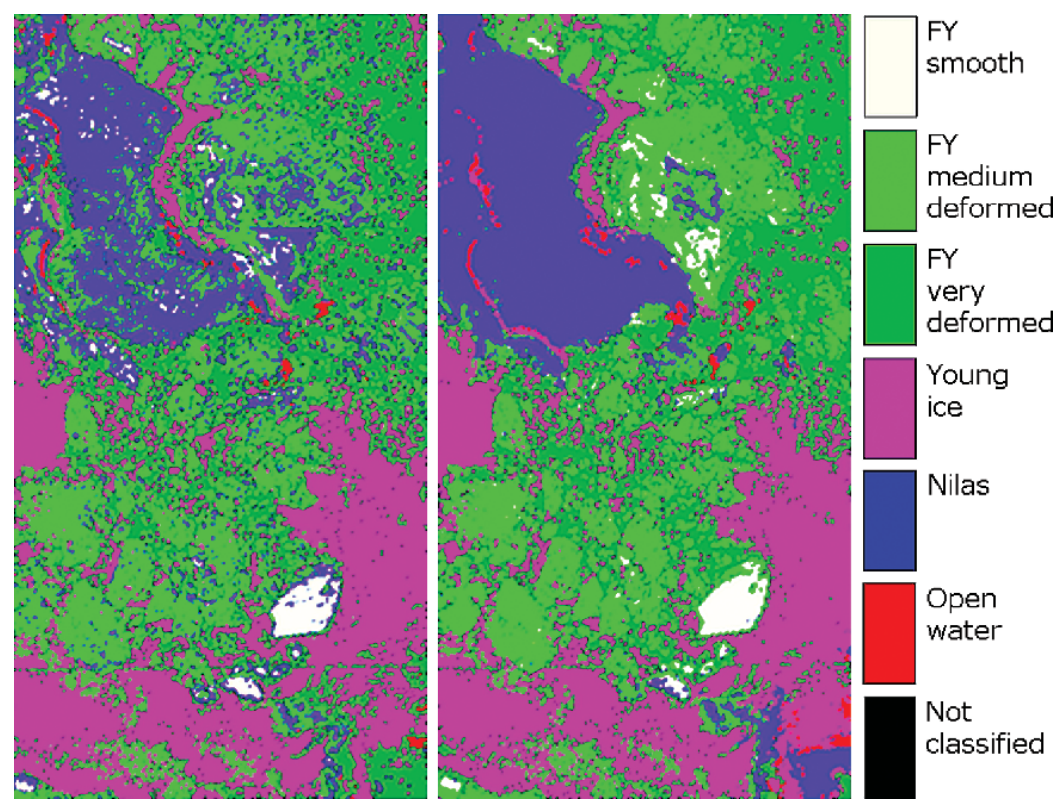

Fig. 2. Results of ice classification based on the multilayer neural network method by Bogdanov et al. (2005) Left: classification results based on ERS and RADARSAT SAR data; right: classification results after including the optical image from Meteor.

\section{Ice drift in the Fram Strait from active and passive microwave data}

Ice drift retrieval from satellite sensors have been developed in the last two decades, using NOAA AVHRR (e.g. Emery et al. 1991), SSM/I and scatterometer (Gohin et al. 1998) as well as high resolution sensors such as SAR (e.g. Kwok 1998) The most common algorithms to retrieve ice drift from satellite data are based on the area-correlation principle (e.g. Fily and Rothrock 1987), where the correspondence is established by matching image patches using their correlation coefficient.

Ice drift in the Fram Strait has been estimated using PMW data with rather coarse resolution since 1978 (Kwok 2004) In this study, wideswath SAR data have been used to estimate ice drift and ice area flux with repeated observations every three days (Figure 3) From February 2004, ice area flux profiles across $79 \mathrm{~N}$ have been calculated using ice drift from 
SAR and ice concentration profiles from PMW data. The ice drift time series shows large short-time variability superimposed on a seasonal cycle, with typical mean velocity is $0.20 \mathrm{~ms}^{-1}$ in winter and $0.10 \mathrm{~ms}^{-1}$ in summer.
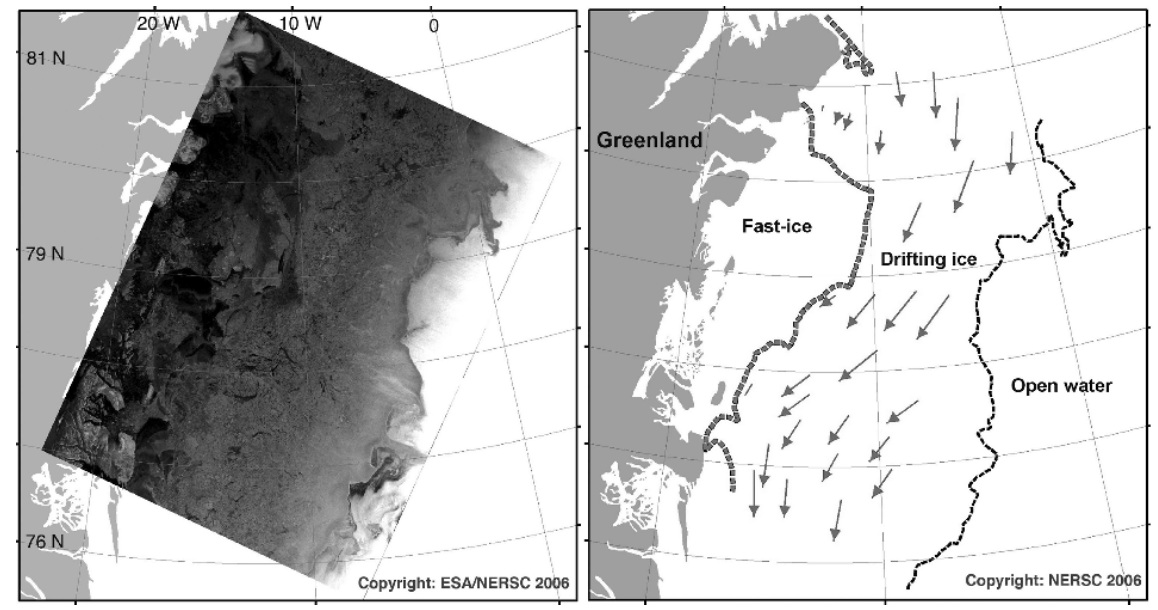

Fig. 3. Left: ASAR Wideswath image from 14 April 2006 covering the sea ice in the Fram Strait; right: Ice drift vectors retrieved from SAR images on 14 and 17 April 2006. The dashed line near the coast of Greenland represent the boundary of the fast-ice, while the dashed line on the right side is the ice edge boundary. Both boundaries are retrieved from the SAR images.

Monthly mean area flux has been estimated from February 2004 to September 2006 as shown in Figure 4. There is a maximum flux in the winter months and a minimum in the summer months, which is in agreement with previous studies (e.g. Kwok et al. 2004) The annual area flux from the SAR data is estimated to be $0.73 \times 10^{6} \mathrm{~km}^{2} /$ year for 2004 and $0.66 \times$ $10^{6} \mathrm{~km}^{2} /$ year for 2005 . Area fluxes retrieved from PMW data from 1978 to 2002 showed a mean value of $0.86 \times 10^{6} \mathrm{~km}^{2} /$ year (Kwok et al. 2004) The SAR-based ice drift was estimated using a correlation algorithm (e.g. Fily and Rothrock 1987) as well as manual analysis to obtain maximum accuracy of the ice drift vectors, estimated to be about $10 \%$ in this region. The SAR ice drift vectors have been interpolated to a $20 \mathrm{~km}$ grid at the $79^{\circ} \mathrm{N}$ latitude in order to resolve the cross strait profile of the ice drift field. The SAR ice drift retrieval is used as a supplement to large-scale ice drift from the scatterometer and PMW data which are only available for the winter months. SAR-based ice drift will also be used to validate ice drift from the PMW and scatterometer data. 


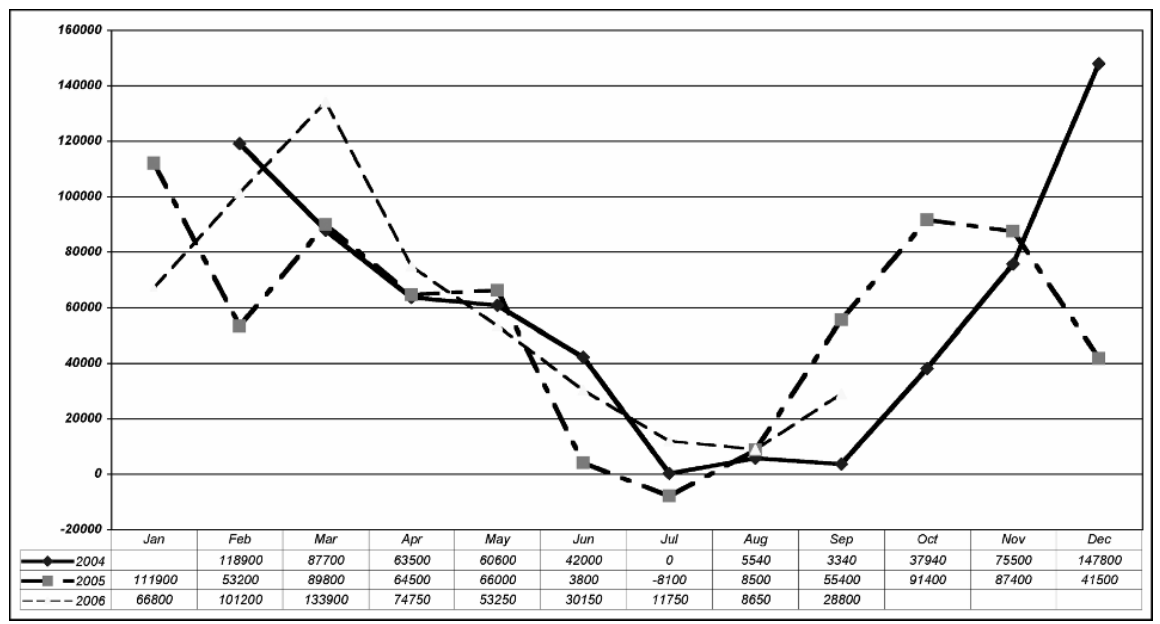

Fig. 4. Monthly ice area flux $\left(\mathrm{km}^{2}\right.$ per month) from SAR ice drift and SSMI ice concentration.

\section{Retrieval of thickness and related sea ice parameters}

Thickness is the most difficult sea ice parameter to observe from satellites and also the parameter with most severe lack of observations. Available data on ice thickness are mainly obtained by non-space methods using upward looking sonars, electromagnetic induction sensors, ice buoys and other in situ measurements techniques.

A method to retrieve ice thickness from thermal infrared (IR) satellite images have been developed for winter conditions for thickness up to about $0.5 \mathrm{~m}$ (Drucker et al. 2003) The IR-method is not very useful for regular observation of ice thickness because of cloud cover limitations. To study the evolution of ice thickness through the whole freezing season, the possibility to use SAR data has been investigated (Kwok and Cunningham 2002) A SAR algorithm based on the RADARSAT Geophysical Processor System (RGPS) has been developed to derive the distribution of thin ice kinematically. By following a large number of ice trajectories throughout an ice growth season, the RGPS tracks the area changes of each Lagrangian cell (Kwok 1998) The ice thickness retrieval uses assumption about freezing rates and ridging due to the deformation of the ice cover. Ice thickness from SAR images have been compared with IR retrievals in the Beaufort Sea and the Canadian Arctic, showing good agreement for new ice being formed in leads (Yu and Lindsay 2003) However, both methods 
have their limitations due to assumptions about snow cover, freezing rates and the amount of ridging as a result of ice deformation.

Russian ice scientists have analyzed AVHRR image since 1979 for thin ice thickness retrieval (Bushuev et al. 2007) An example of ice thickness map in the eastern Barents Sea is shown in Figure 5 where validation data from coastal stations and ship observations show generally good agreement with the satellite retrievals.

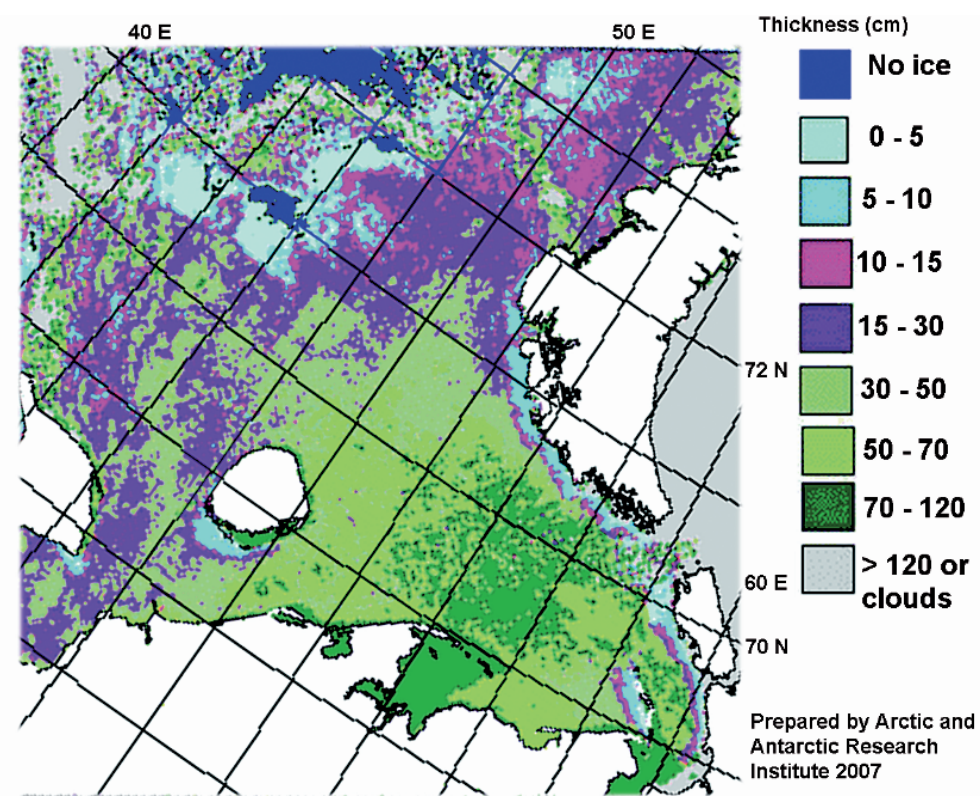

Fig. 5. Example of the ice thickness in the Barents Sea derived from NOAA AVHRR IR image on May 4, 2001, 08:20GMT, prepared by Arctic and Antarctic Research Institute (Johannessen et al. 2007).

Retrieval of thin ice thickness from SSM/I data, as complementary method to the IR technique, has been demonstrated by Martin et al (2004) in the Bering Sea. These studies showed that $10-20 \mathrm{~cm}$ thin ice in refreezing polynyas could be determined using the vertical to horizontal ratio of the $37 \mathrm{GHz}$ brightness temperature. This method has been adapted to AMSR-E data to improve the resolution of thin ice thickness estimation and heat flux retrieval in polynyas (Martin et al. 2005) Use of SAR data has been an important part of recent heat flux and thin ice studies, because SAR can provide accurate definition of polynya areas and estimates of polynya evolution.

A promising new technique to retrieve sea-ice thickness from satelliteborne altimeter data has been developed and tested on ERS-1/2 altimeter data 
(Laxon et al. 2003) Also laser altimeter data have shown capability to provide synoptic data on ice thickness across the Arctic Ocean (Kwok et al. 2006) CryoSat, scheduled for launched in 2009, will carry an improved radar altimeter that has ice thickness measurements as a key objective.

\section{Observing icebergs in Arctic ice-covered seas}

Until now, satellite data can only observe large icebergs, typically $100 \mathrm{~m}$ or more in horizontal extent, under favourable cloud, wind and sea ice conditions. Studies on icebergs detection in satellite images have been conducted in several areas in the Northern hemisphere, such as in eastern Canada (Power et al. 2001), off the coast of Greenland (e.g. Gill 2001) and in the northern Barents Sea (Kloster and Spring 1993; Sandven et al. 1999)

In this study the iceberg detection capability of ENVISAT ASAR alternating polarization images (AP) and RADARSAT ScanSAR Narrow (SN) mode is compared with Landsat optical images in April 2006. A selection of 15 icebergs of size from 50 to $400 \mathrm{~m}$ were identified in a subset of a Landsat panchromatic image (pixel size $15 \mathrm{~m}$ ) covering the southern part of the Franz Josef Land archipelago (Figure 6a). The subimage covered about 30 by $30 \mathrm{~km}$ and overlapped with the SAR AP image (Figure 6b). It should be mentioned that several hundred icebergs could be identified in the whole Landsat image, but only a small subset was selected for further analysis. In optical images icebergs are identified as bright objects against a less bright background combined with a dark shadow due to low sun angle and height of the iceberg. In SAR images icebergs are also identified as bright objects, but detection capability depends on the backscatter of the surrounding sea ice or open water.

The HH image had better signal-to-noise ratio for all 15 icebergs compared to the VV image. Both $\mathrm{HH}$ - and VV-image showed many bright spots that were not identified as any object in the Landsat image. A comparison with a RADARSAT ScanSAR Narrow image with pixel size of $25 \mathrm{~m}$ and $\mathrm{HH}$ polarization was also done. Four of the smaller icebergs could not be identified, suggesting that $25 \mathrm{~m}$ pixel size in the RADARSAT image compared to the $12.5 \mathrm{~m}$ pixels in the AP image makes a difference.

For iceberg detection in the Barents Sea region, image resolution both in SAR and optical images should be better than $10 \mathrm{~m}$. Further studies are needed to compare iceberg size and shape data from ship and aircraft with satellite data. Since future SAR systems will have different polarization options, it is important to determine which SAR modes should be used for iceberg detection. 


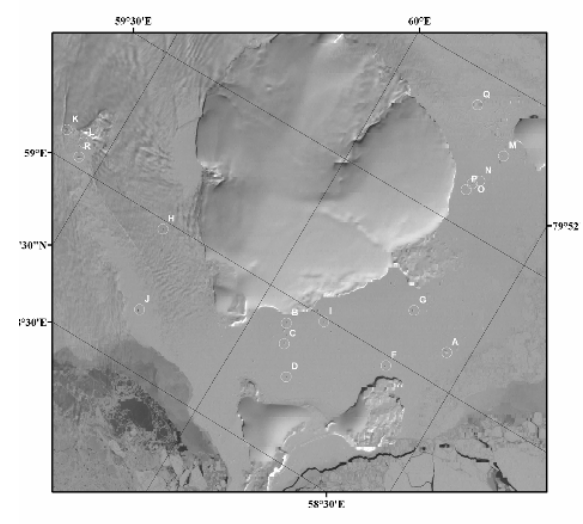

a

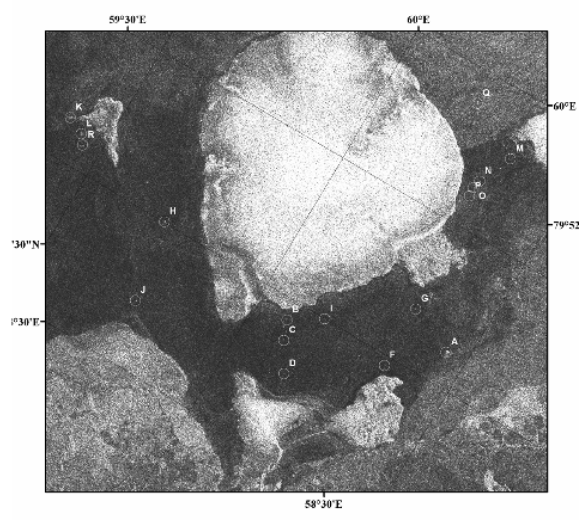

b

Fig. 6. (a) Landsat subimage from the southern part of Franz Josef Land region obtained on 14 April 2006. A selection of icebergs with horizontal scale from 50 to $400 \mathrm{~m}$ are identified and marked by circles (A - R); (b) ENVISAR ASAR Alternating Polarization image from 12 April 2006, available in both $\mathrm{HH}$ - and VVpolarization. The subimage covers the same areas as the Landsat image and the same icebergs are indicated as in (a).

\section{Conclusions}

Polar orbiting satellites produce an increasing amount of data from several sensors that can be exploited in sea ice observation. In this study, four examples of multi-sensor observations of sea ice and icebergs parameters have been described, demonstrating the benefit of combining data from several sensors to produce higher quality sea ice information. For regional monitoring of ice concentration and ice types, use of high-resolution radar and optical/infrared images can improve the quality of ice classification. For ice drift estimation, synergetic use of scatterometer and PMW data has shown promising results in large-scale mapping, while SAR data are useful for regional mapping of ice drift with higher resolution. Iceberg observations can benefit from the combined use of radar and optical/infrared images, and by increasing image resolution to better than $10 \mathrm{~m}$.

A major task in the coming years will be to exploit new SAR data (RADARSAT-2, ALOS, TerraSAR-X, Sentinel), with multi-polarization capability in combination, altimeter data (IceSat, CryoSat), optical/IR and PMW data, to improve observation of sea ice thickness, motion and fluxes. 


\section{Acknowledgements}

The studies have been supported by the EU MERSEA Integrated project, the Norwegian SatOcean project, and Hydro Oil and Energy.

\section{References}

Andersen S, Tonboe R, Kern S, Schyberg H (2006) Improved retrieval of sea ice total concentration from spaceborne passive microwave observations using numerical weather prediction model fields: An intercomparison of nine algorithms. Remote Sensing of Environment 104: 374-392

Bogdanov A, Sandven S, Johannessen OM, Alexandrov VY, Bobylev LP (2005) Multisensor approach to automated classification using sea ice image data. IEEE Trans Geosci Rem Sens 43 (7): 1648-1664

Bogdanov AV, Sandven S, Johannessen OM, Alexandrov VY, Bobylev LP, Loshchilov VS (2007) Sea ice retrieval algorithms for SAR. In: Johannessen OM et al. (eds) Polar Seas Oceanography. Remote Sensing of Sea ice in the Northern Sea Route: Studies and Applications. Praxis Springer 220-243

Bushuev AV, Loshchilov VS, Shcherbahov YA, Paramonov AI (2007) Satellite Remote Sensing of sea ice: Optical and Infrared Imaging. In: Johannessen OM et al. (eds) Polar Seas Oceanography. Remote Sensing of Sea ice in the Northern Sea Route: Studies and Applications. Praxis Springer 149-171

Drucker R, Martin S, Moritz R (2003) Observations of ice thickness and frazil ice in the St. Lawrence Island polynya from satellite imagery, upward looking sonar, and salinity/temperature moorings. J Geophys Res 108 (C5): 3149, doi:10.1029/ 2001JC001213

Emery WJ, Fowler CW, Hawkins J, Preller RH (1991) Fram Strait satellite imagederived ice motions. J Geophys Res 96: 4751-4768

Fily M, Rothrock DA (1987) Sea ice tracking by nested correlations. IEEE Trans Geosci Rem Sens GE 25 (5): 570-580

Gill RS (2001) Operational detection of sea ice edges and icebergs using SAR. Canadian J Rem Sens 27 (5): 411-232

Gohin F, Cavanié A, Ezraty R (1998) Evolution of passive and active microwave signatures of a large sea ice feature during its two and half year drift through the Arctic Ocean. J Geophys Res 103 (C4): 8177-8189

Johannessen OM, Shalina EV, Miles MW (1999) Satellite Evidence for an Arctic Sea Ice cover in Transformation. Science 286: 1937-1939

Johannessen OM, Bengtsson L, Miles MW, Kuzmina SI, Semenov VA, Alekseev GV, Nagurnyi AP, Zakharov VF, Bobylev LP, Pettersson LH, Hasselmann K, Cattle HP (2004) Arctic climate change: observed and modeled temperature and sea-ice variability. Tellus, Series A 56A (4): 328-341

Johannessen OM, Alexandrov VY, Frolov IY, Sandven S, Miles M, Bobylev LP, Pettersson LH, Smirnov VG, Mironov EU, eds (2007) Polar Seas Oceanography. 
Remote Sensing of Sea ice in the Northern Sea Route: Studies and Applications. Praxis Springer, pp 472

Kloster K, Spring W (1993) Iceberg and glacier mapping using satellite optical imagery during the Barent Sea Ice Data Acquisition Program (IDAP). Proc 12th Int Conf Port and Ocean Engineering under Arctic Conditions, Hamburg. 17-20 August 1993, vol 1, pp 413-424

Kwok R (1998) The RADARSAT Geophysical Processor System. In: Tsatsoulis C, Kwok R (eds) Analysis of SAR data of the Polar Oceans. Springer Verlag, Berlin, pp 235-258

Kwok R, Cunningham GF (2002) Seasonal ice area and volume production of the Arctic Ocean: November 1996 through April 1997. J Geophys Res 107 (C10): 8038, doi:10.1029/2000JC000469

Kwok R, Cunningham GF, Pang SS (2004) Fram Strait sea ice outflow. J Geophys Res 109, C01009, doi:10.1029/2003JC001785

Kwok R, Cunninham GF, Zwally HJ, Yi D (2006) ICESat over Arctic sea ice: interpretation of altimetric and reflectivity profiles. J Geophys Res 111, C06006, doi: 10.1029/2005JC003175

Laxon S, Peacock N, Smith D (2003) High interannual variability of sea ice thickness in the Arctic region. Nature 245: 947-950

Martin S, Drucker R, Kwok R, Holt B (2004) Estimation of the thin ice thickness and heat flux for the Chukchi Sea Alaskan coast polynya from SSM/I data, 1990 - 2001. J Geophys Res,109, C10012, doi:10.1029/2004JC002428

Martin S, Drucker R, Kwok R, Holt B (2005) Improvements in the estimates of ice thickness and production in the Chukchi Sea polynyas derived from AMSR-E. Geophy. Res Lett 32, L05505, doi:10.1029/2004GL022013

Onstott RG, Shuchman RA (2004) SAR measurements of sea ice. In: Jackson CR, ApelJR (eds) Synthetic Aperture Radar. Marine User's Manual, National Oceanic and Atmospheric Administration, US Department of Commerce, Washington DC, pp 81-115

Power D, Youden J, Lane K, Randell C, Flett D (2001) Iceberg detection capabilities of RADARSAT Synthetic Aperture Radar. Canadian J Rem Sens 27 (5): 476-486

Sandven S, Johannessen OM, Miles M, Pettersson LH, Kloster K (1999) Barents Sea seasonal ice zone features and processes from ERS-1 SAR. J Geophys Res 104 (C7): 15843-15857

Tsatsoulis C, Kwok R, eds (1998) Analysis of SAR data of the Polar Oceans. Recent Advances. Springer Verlag, Heidelberg

Yu Y, Lindsay RW (2003) Comparison of thin ice thickness distributions derived from RADARSAT Geophysical Processor System and advanced very high resolution radiometer data sets. J Geophys Res 108 (C12), 3387, doi:10.1029/ 2002JC001319, 2003 